\title{
Prevalence and incidence of vector-borne pathogens in unprotected dogs in two Brazilian regions
}

Filipe Dantas-Torres ${ }^{1 *} \mathbb{0}$, Luciana Aguiar Figueredo ${ }^{1}$, Kamila Gaudêncio da Silva Sales ${ }^{1}$, Débora Elienai de Oliveira Miranda ${ }^{1}$, Joanna Lúcia de Almeida Alexandre ${ }^{1}$, Yury Yzabella da Silva', Lidiane Gomes da Silva², Guilherme Ribeiro Valle³, Vitor Márcio Ribeiro ${ }^{3}$, Domenico Otranto ${ }^{4,5}$, Katrin Deuster ${ }^{6}$, Matthias Pollmeier ${ }^{6}$ and Gertraut Altreuther ${ }^{6}$

\begin{abstract}
Background: Various vector-borne pathogens (VBPs) affect dogs worldwide, with their diversity and force of infection being usually higher in the tropics. Cross-sectional studies have been conducted to investigate the prevalence of VBPs in dogs, but data from longitudinal studies are scarce. Herein, we assessed the prevalence and the year-crude incidence (YCI) of Leishmania spp. and other VBPs in privately-owned dogs from two geographical regions of Brazil.

Methods: A total of 823 dogs were initially screened for Leishmania spp. by both serology and polymerase chain reaction (PCR). From the negatives, 307 (103 from São Joaquim de Bicas, Minas Gerais, and 204 from Goiana, Pernambuco) were randomly selected for the longitudinal study. These dogs were tested for various VBPs at baseline, after 8 and 12 months.

Results: Out of 823 dogs initially screened, 131 (15.9\%) were positive for Leishmania spp. Out of the 307 dogs enrolled in the longitudinal study, 120 (39.1\%) were lost for different reasons (e.g. animal death, owner decision, and lost to follow-up). In São Joaquim de Bicas, the baseline prevalence and $\mathrm{YCl}$ were as follows: $16.5 \%$ and $7.1 \%$ for Anaplasma spp.; $81.6 \%$ and $100 \%$ for Babesia spp.; $0 \%$ and 1.3\% (only one faint positive) for Dirofilaria immitis; $37.9 \%$ and 22.9\% for Ehrlichia spp.; $19.5 \%$ and $43.8 \%$ for Leishmania spp. In Goiana, the baseline prevalence and YCI were as follows: $45.1 \%$ and $38.3 \%$ for Anaplasma spp.; $79.9 \%$ and $96.0 \%$ for Babesia spp.; $36.3 \%$ and $39.8 \%$ for D. immitis; 64.7\% and 58.5\% for Ehrlichia spp.; 14.7\% and 19.6\% for Leishmania spp. Anti-Borrelia burgdorferi antibodies were not detected in any of the samples tested herein. The prevalence and YCl of Anaplasma spp., D. immitis and Ehrlichia spp. were significantly higher in Goiana. In contrast, the YCl of Leishmania spp. infection was significantly higher in São Joaquim de Bicas.
\end{abstract}

Conclusions: We confirmed a high prevalence and $\mathrm{YCl}$ of various VBPs among privately-owned dogs in two geographical regions of Brazil. Our data also indicate that the risk of infection varies significantly for individual VBPs and between the regions, which may be related to several factors that are still poorly understood.

Keywords: Anaplasma, Babesia, Dirofilaria, Ehrlichia, Leishmania, Dogs, Prevalence, Incidence

*Correspondence: filipe.dantas@cpqam.fiocruz.br

1 Department of Immunology, Aggeu Magalhães Institute, Oswaldo Cruz Foundation (Fiocruz), Recife, Brazil

Full list of author information is available at the end of the article

c) The Author(s) 2020. This article is licensed under a Creative Commons Attribution 4.0 International License, which permits use, sharing, adaptation, distribution and reproduction in any medium or format, as long as you give appropriate credit to the original author(s) and the source, provide a link to the Creative Commons licence, and indicate if changes were made. The images or other third party material in this article are included in the article's Creative Commons licence, unless indicated otherwise in a credit line to the material. If material is not included in the article's Creative Commons licence and your intended use is not permitted by statutory regulation or exceeds the permitted use, you will need to obtain permission directly from the copyright holder. To view a copy of this licence, visit http://creativeco mmons.org/licenses/by/4.0/. The Creative Commons Public Domain Dedication waiver (http://creativecommons.org/publicdomain/ zero/1.0/) applies to the data made available in this article, unless otherwise stated in a credit line to the data. 


\section{Background}

A wide range of vector-borne pathogens (VBPs), including bacteria, protozoa and filarial nematodes, can infect and eventually cause overt disease in domestic dogs worldwide [1-4]. These pathogens are transmitted to dogs, and eventually to other hosts, through various arthropod vectors, such as ticks, mosquitoes, phlebotomine sand flies, fleas, lice, and triatomine bugs [5].

Due to its unique climate and landscape types [6], the tropics are unique also in terms of diversity and abundance of arthropod vectors and their associated pathogens. For instance, an extraordinary diversity of ticks, mosquitoes, and phlebotomine sand flies may feed on dogs in the tropics, with many of these species restricted to this climate zone [7]. Moreover, the favourable climate found in most of the tropics provides the opportunity for VBP transmission to occur during the entire year [8], further increasing the risk of infection in dogs and, eventually, in humans $[9,10]$.

Brazil is an epicentre of VBP transmission in Latin America and Caribbean [11], not only in dogs, but also in humans [7]. Indeed, diseases like leishmaniasis, Chagas disease, malaria, dengue fever, and lymphatic filariasis, just to mention a few, are still responsible for a heavy burden, affecting disproportionally the poorest of the poor [12]. Dogs living in Brazil are also afflicted by numerous VBPs such as Babesia vogeli, Dirofilaria immitis, Ehrlichia canis and Leishmania infantum [7]. Additionally, they are also affected by pathogens that are restricted to Latin America, including Leishmania amazonensis, Leishmania braziliensis and Rangelia vitalii [7].

While several cross-sectional studies on VBPs infecting dogs have been conducted in the tropics, longitudinal studies are very scant and, for some pathogens, virtually inexistent. For instance, a few longitudinal studies on $L$. infantum infection in dogs have been conducted in Brazil (e.g. $[13,14])$, a zoonotic parasite that still affects and kills thousands of Brazilians every year [15]. As a result, there is very limited information about the annual incidence of VBP infections in dogs, in spite of the large number of cross-sectional studies available in the literature (e.g. [16-20]). Prevalence data cannot per se be used to infer incidence, also considering that seroconversion may take months to occur and that antibodies produced against certain pathogens may last for months.

In this context, we estimated the year-crude incidence (YCI) of infection by Leishmania spp. in dogs from two municipalities of Brazil, based on data gathered from two cohorts of privately-owned dogs followed up for 1 year and whose new infections were diagnosed by serological and molecular tests. Additionally, infections by other VBPs were also investigated.

\section{Methods}

Study areas

This study was conducted from September 2015 to November 2016, in two urban areas. The first site was the municipality of Goiana $\left(7^{\circ} 33^{\prime} 39^{\prime \prime} \mathrm{S}, 35^{\circ} 0^{\prime} 10^{\prime \prime} \mathrm{W}\right.$; altitude: $13 \mathrm{~m}$ ), located $\sim 62 \mathrm{~km}$ from Recife, the capital of Pernambuco State, north-eastern Brazil. Goiana has a tropical savanna climate with dry-summer characteristics, which corresponds to the Köppen climate classification categories "Aw" and "As". The mean annual temperature and precipitation are $24.9^{\circ} \mathrm{C}$ and $1924 \mathrm{~mm}$, respectively. The mean monthly temperature ranges from $23.3{ }^{\circ} \mathrm{C}$ to $26{ }^{\circ} \mathrm{C}$, whereas the mean monthly precipitation ranges from $46 \mathrm{~mm}$ to $307 \mathrm{~mm}$.

The second site was the municipality of São Joaquim de Bicas $\left(20^{\circ} 02^{\prime} 56^{\prime \prime} \mathrm{S}, 44^{\circ} 16^{\prime} 26^{\prime \prime} \mathrm{W}\right.$, altitude: $\left.755 \mathrm{~m}\right)$, located $\sim 45 \mathrm{~km}$ far from Belo Horizonte, the capital of Minas Gerais State, south-eastern Brazil. São Joaquim de Bicas has a humid subtropical climate with dry-winter characteristics, which corresponds to the Köppen climate classification category "Cwa". The mean annual temperature and precipitation are $21.5^{\circ} \mathrm{C}$ and $1348 \mathrm{~mm}$, respectively. The mean monthly temperature ranges from $18.3{ }^{\circ} \mathrm{C}$ to $23.9{ }^{\circ} \mathrm{C}$, whereas the mean monthly precipitation ranges from $10 \mathrm{~mm}$ to $287 \mathrm{~mm}$.

These municipalities were chosen because a previous cross-sectional study confirmed the presence of various VBPs in privately-owned dogs [19]. Further details on these sites can be found elsewhere [19].

\section{Dog population and sampling}

The study population included initially 823 privatelyowned dogs, which were screened for anti-Leishmania spp. antibodies. Part $(n=632)$ of these dogs was also tested for Leishmania minicircle kinetoplast DNA (kDNA) by real-time PCR. From the negatives to both serology and PCR, and complying with some inclusion criteria (i.e. dogs should be in general good healthy, nonfractious, untreated with ectoparasiticides with known efficacy against VBPs, availability of written owner consent form), 307 (168 males and 139 females) dogs were randomly selected for the longitudinal study. Selected dogs were mostly mongrels, with age ranging from 2 months to 13 years (average $=2.7$ years). Except for 76 dogs whose owners reported (at least once) the use of ectoparasiticides (39 in Goiana, 37 in São Joaquim de Bicas), all dogs were not treated to prevent ectoparasite infestations throughout the entire observation period.

At baseline, after 8 and 12 months, a $5 \mathrm{ml}$ blood sample was collected from each dog, from the brachial, jugular or other suitable vein. Approximately $3 \mathrm{ml}$ of blood were added to $\mathrm{BD} \mathrm{SST}^{\mathrm{TM}}$ gel tubes and the remaining blood $(2 \mathrm{ml})$ were collected in EDTA (purple cap) collection 
tubes. At the laboratory, $\mathrm{BD} \mathrm{SST}^{\mathrm{TM}}$ gel tubes were centrifuged at $2000 \times g$ for $10 \mathrm{~min}$ for serum separation. Aliquots of sera were then immediately tested as described below. Remaining serum samples and EDTA-blood samples were frozen at $-20^{\circ} \mathrm{C}$.

\section{Serological testing}

For the initial screening, dogs were tested for antibodies to Leishmania spp. using at least one of the following tests: ELISA $/ S 7^{\circledR}$ (Biogene), DPP LVC (Bio-Manguinhos), Alere Leishmaniose Ac Test (Alere), SNAP ${ }^{\circledR}$ Leishmania Test (IDEXX Laboratories, Maine, USA). All dogs randomly selected for the longitudinal study had to be negative by the SNAP ${ }^{\circledR}$ Leishmania Test (and also by PCR), which was the one used to retest the dogs after 8 and 12 months.

All dogs included in the longitudinal study were also tested (at baseline, after 8 and 12 months) by a rapid ELISA (SNAP ${ }^{\circledR}$ 4Dx Plus Test, IDEXX Laboratories, Maine, USA) that detected antibodies to Anaplasma spp. (A. platys/A. phagocytophilum), Ehrlichia spp. (E. canis/E. ewingii), and Borrelia burgdorferi, and antigens of Dirofilaria immitis. Likewise, dogs were tested by an indirect immunofluorescence (IFA) that detected antibodies to Babesia spp. (Babesia canis IFA IgG Antibody Kit, Fuller Laboratories), with a cut-off of 1:50. All serological tests were performed using serum samples and according to the manufacturer's instructions.

\section{Molecular testing}

EDTA-treated blood samples collected from dogs were subjected to DNA extraction, using a commercial kit (PureLink ${ }^{\circledR}$ Mini Kit, Invitrogen, Carlsbad, CA, USA), according to the manufacturer's instructions. The quantity and purity of the extracted DNA were assessed using a NanoDrop 2000c Spectrophotometer (Thermo Fisher Scientific, Waltham, MA, USA) and samples were then stored at $-20^{\circ} \mathrm{C}$.

Leishmania spp. kDNA was detected by real-time PCR as described elsewhere [20,21], using the primers LEISH-1 (5'-AAC TTT TCT GGT CCT CCG GGT AG-3') and LEISH-2 (5'-ACC CCC AGT TTC CCG CC- $3^{\prime}$ ) and the TaqMan ${ }^{\circledR}$ probe FAM-5'-AAA AAT GGG TGC AGA AAT-3'-non-fluorescent quencher-MGB [21]. Each reaction contained a final volume of $15 \mu \mathrm{l}$, including $7.5 \mu \mathrm{l}$ of TaqMan ${ }^{\circledR}$ Fast Advanced Master Mix (Applied Biosystems, Carlsbad, CA, USA), $1.35 \mu \mathrm{l}$ of each primer (at a concentration of $900 \mathrm{nM}$ ), $0.3 \mu \mathrm{l}$ of probe (at $200 \mathrm{nM}$ ), $2 \mu \mathrm{l}$ of DNA sample, $2.5 \mu \mathrm{l}$ of DNA-free water. Thermal cycling conditions were as follows: denaturation at $95{ }^{\circ} \mathrm{C}$ for $20 \mathrm{~s}$, and 40 cycles at $95^{\circ} \mathrm{C}$ for $1 \mathrm{~s}$ and $60{ }^{\circ} \mathrm{C}$ for $20 \mathrm{~s}$ [22]. A standard curve was prepared from L. infantum genomic DNA (MHOM/BR/76/M4192) at different concentrations $(1 \mathrm{ng}, 100 \mathrm{pg}, 10 \mathrm{pg}, 1 \mathrm{pg}$,
$100 \mathrm{fg}, 10 \mathrm{fg}, 1 \mathrm{fg}, 0.1 \mathrm{fg}$ and $0.01 \mathrm{fg}$ per reaction). A master mix with no DNA was used as no template control (NTC). Real-time PCR reactions were performed using QuantStudio ${ }^{\circledR} 5$ Real-Time PCR system (Applied Biosystems, Foster City, CA, USA) and results were analysed using QuantStudio Design and Analysis Software v1.4 (Applied Biosystems, Foster City, CA, USA).

Babesia spp. DNA was detected by conventional PCR using the primers BcanisF (5'-GCA TTT AGC GAT GGA CCA TTC AAG-3') and Bcommon-R (5'-CCT GTA TTG TTA TTT CTT GTC ACT ACC TC-3'), as described elsewhere [23]. Each reaction contained $8.5 \mu \mathrm{l}$ of DNA-free water, $12.5 \mu \mathrm{l}$ of $\mathrm{GoTaq}^{\circledR}$ Colorless Master Mix (Promega, Madison, USA), $1.0 \mu \mathrm{l}$ of each primer at a concentration of $25 \mathrm{pmol} / \mu \mathrm{l}$ and $2 \mu \mathrm{l}$ of DNA sample. Thermal cycling conditions were as follows: initial denaturation at $95^{\circ} \mathrm{C}$ for $2 \mathrm{~min}$, followed by 35 cycles of $95^{\circ} \mathrm{C}$ for $45 \mathrm{~s}, 60{ }^{\circ} \mathrm{C}$ for $45 \mathrm{~s}$ and $72{ }^{\circ} \mathrm{C}$ for $1 \mathrm{~min}$, and a final extension step at $72{ }^{\circ} \mathrm{C}$ for $5 \mathrm{~min}$. DNA extracted from the blood of a dog infected by $B$. vogeli was used as positive control and a master mix with no DNA as NTC.

Anaplasma platys DNA was detected by conventional PCR using the GroAplatys-35s (5' - AGC GTA GTC CGA TTC TCC AGT TTT-3') and GroAplatys-550as (5'- TCG CCG TTA GCA GAG ATG GTA G-3'), as described elsewhere [24]. Each reaction contained $7.5 \mu \mathrm{l}$ of DNA-free water, $12.5 \mu$ lof $\mathrm{GoTaq}^{\circledR}$ Colorless Master Mix (Promega, Madison, USA), $1.5 \mu \mathrm{l}$ of each primer at a concentration of $10 \mathrm{pmol} / \mu \mathrm{l}$ and $2 \mu \mathrm{l}$ of DNA sample. Thermal cycling conditions were as follows: denaturation at $95^{\circ} \mathrm{C}$ for $1 \mathrm{~min}$, followed by 55 cycles of $94{ }^{\circ} \mathrm{C}$ for $15 \mathrm{~s}, 62{ }^{\circ} \mathrm{C}$ for $15 \mathrm{~s}$ and $72{ }^{\circ} \mathrm{C}$ for $15 \mathrm{~s}$, and a final extension step at $72^{\circ} \mathrm{C}$ for $7 \mathrm{~min}$. DNA extracted from the blood of a dog infected by $A$. platys was used as positive control and a master mix with no DNA as NTC.

Ehrlichia canis DNA was detected by conventional PCR using the primers gro-E.canis163s (5'-AAA TGT AGT TGT AAC GGG TGA ACA G-3') and gro-E.canis573as (5'- AGA TAA TAC CTC ACG CTT CAT AGA CA-3'), as described elsewhere [25]. Each reaction contained $7.5 \mu \mathrm{l}$ of DNA-free water, $1.5 \mu \mathrm{l}$ of each primer at a concentration of $10 \mathrm{pmol} / \mu \mathrm{l}, 12.5 \mu \mathrm{l} \mathrm{GoTaq}{ }^{\circledR}$ Colorless Master Mix (Promega, Madison, USA) and $2 \mu \mathrm{l}$ of the sample DNA to be tested. Thermal cycling conditions were as follows: denaturation at $95^{\circ} \mathrm{C}$ for $30 \mathrm{~s}$, followed by 40 cycles of $94{ }^{\circ} \mathrm{C}$ for $10 \mathrm{~s}, 62^{\circ} \mathrm{C}$ for $15 \mathrm{~s}$ and $72^{\circ} \mathrm{C}$ for $15 \mathrm{~s}$, with a final extension step at $72{ }^{\circ} \mathrm{C}$ for $1 \mathrm{~min}$. DNA extracted from the blood of a dog infected by $E$. canis was used as positive control and a master mix with no DNA as NTC.

All conventional PCR assays were run on a $\mathrm{Veriti}^{\circledR}$ 96-Well Thermal Cycler (Applied Biosystems, Foster City, CA, USA) and amplicons were analysed by $1.5 \%$ agarose gel electrophoresis and visualized in ultraviolet light. 


\section{Statistical analysis}

Baseline prevalence was calculated for each of the two study locations considering dogs positive to one or more tests. Baseline prevalence for Leishmania spp. was calculated using data from all dogs initially screened, whereas for other pathogens it was calculated using data from dogs included in the longitudinal study. Exact $95 \%$ confidence intervals $(95 \% \mathrm{CI})$ were calculated for each baseline prevalence.

YCI was expressed as percentage and calculated considering the number of dogs positive at the interim and/ or at the final follow-up, using the following formula: number of positive dogs/(number of negative dogs at baseline - number of dogs lost to follow up) $\times 100$. For calculation purposes, "dogs lost to follow up" were those tested at baseline but removed from the study before the interim follow-up (i.e. not retested in the study). Likewise, we used the last observation carried forward (LOCF) method, so data from dogs tested at the interim follow-up, but removed before the final follow-up were included in the calculations. Finally, dogs positive at the interim follow-up and eventually negative at the final follow-up were considered as positive.

The differences in baseline prevalence and YCI for each pathogen between dogs from São Joaquim de Bicas and Goiana were tested using Chi-square test, with a $P<0.05$ considered statistically significant. Calculations and statistical analyses were performed using GraphPad QuickCalcs (http://www.graphpad.com/quickcalcs/) and BioEstat, version 5.3 (Instituto de Desenvolvimento Sustentável Mamirauá, Belém, Pará, Brazil).

\section{Results and discussion}

Out of 823 dogs initially screened, 131 (15.9\%; 95\% CI: 13.6-18.6\%) were positive for anti-Leishmania spp. antibodies or to Leishmania kDNA (Additional file 1: Table S1), with a higher positivity in São Joaquim de Bicas (19.5\%) as compared to Goiana (14.7\%), although this difference was not statistically significant. Our previous study with a much smaller sample size also suggested a higher prevalence of Leishmania spp. infection in dogs from São Joaquim de Bicas as compared to Goiana [19]. A previous study conducted in Natal (Rio Grande do Norte state, north-eastern Brazil) reported that higher owner education was associated with decreased levels of dog seropositivity to Leishmania spp. [26]. While the illiteracy rate is generally higher in Goiana as compared to São Joaquim de Bicas, a detailed analysis of individual dog owner education level would be necessary to assess whether this could be a main driver for the higher prevalence and YCI in São Joaquim de Bicas.

Out of the 307 privately-owned dogs enrolled in the longitudinal study, 120 (39.1\%) were lost during the 1-year observation period for different reasons (e.g. animal death, owner decision, and lost to follow-up). The losses were higher in Goiana $(n=87 ; 42.7 \%)$ as compared to São Joaquim de Bicas $(n=33 ; 32.0 \%)$.

Comparative analyses revealed statistically significant differences between the baseline prevalence (Table 1) and/or YCI (Table 2) of some VBP infections in dogs from São Joaquim de Bicas and Goiana. In particular, the baseline prevalence and the YCI of Anaplasma spp., D. immitis and Ehrlichia spp. were significantly higher in Goiana. In contrast, the YCI of Leishmania spp. was significantly higher in São Joaquim de Bicas. The significantly higher YCI of Leishmania spp. infection in dogs from São Joaquim de Bicas suggests that dogs and people living in this municipality are at a higher risk of Leishmania spp. infection as compared to Goiana. According to official data at state level, the incidence of human visceral leishmaniasis in 2016 was 2.32 and 0.77 per 100,000 inhabitants in Minas Gerais and Pernambuco, respectively [15]. The higher incidence of human visceral leishmaniasis in Minas Gerais [15] may be due to many determinant factors, including higher exposure to sand fly vectors, which may be ultimately related to poor housing conditions, higher vector densities, or both.

Table 1 Baseline prevalence of various vector-borne pathogens in Goiana (Pernambuco) and São Joaquim de Bicas (Minas Gerais), Brazil

\begin{tabular}{|c|c|c|c|c|c|}
\hline \multirow[t]{2}{*}{ Pathogen $^{a}$} & \multicolumn{2}{|l|}{ Goiana } & \multicolumn{2}{|c|}{ São Joaquim de Bicas } & \multirow[t]{2}{*}{ Statistics } \\
\hline & Prevalence (\%) & $95 \% \mathrm{Cl}$ & Prevalence (\%) & $95 \% \mathrm{Cl}$ & \\
\hline Anaplasma spp. & $45.1(n=204)$ & $38.1-52.2$ & $16.5(n=103)$ & $9.9-25.1$ & $X^{2}=24.44, d f=1, P<0.0001$ \\
\hline Babesia spp. & $79.9(n=204)$ & $73.7-85.2$ & $81.6(n=103)$ & $72.7-88.5$ & $X^{2}=0.12, d f=1, P=0.7304$ \\
\hline Dirofilaria immitis & $36.3(n=204)$ & $29.7-43.3$ & $0(n=103)$ & $\mathrm{nc}$ & $x^{2}=49.23, d f=1, P<0.0001$ \\
\hline Ehrlichia spp. & $64.7(n=204)$ & $57.9-70.9$ & $37.9(n=103)$ & $28.5-48.0$ & $x^{2}=19.99, d f=1, P<0.0001$ \\
\hline Leishmania spp. & $14.7(n=516)$ & $11.8-18.1$ & $19.5(n=307)$ & $15.5-24.4$ & $x^{2}=3.24, d f=1, P=0.0721$ \\
\hline
\end{tabular}

${ }^{a}$ Except for Dirofilaria immitis and Borrelia burgdorferi (not shown in the table), all pathogens were assessed by both serology and PCR. For more details, see "Methods" and Additional file 1:Table S1 
Table 2 Year-crude incidence of various vector-borne pathogens in Goiana (Pernambuco) and São Joaquim de Bicas (Minas Gerais), Brazil

\begin{tabular}{|c|c|c|c|c|c|}
\hline \multirow[t]{2}{*}{ Pathogens $^{\mathrm{a}}$} & \multicolumn{2}{|l|}{ Goiana } & \multicolumn{2}{|l|}{ São Joaquim de Bicas } & \multirow[t]{2}{*}{ Statistics } \\
\hline & Year-crude incidence (\%) & $95 \% \mathrm{Cl}$ & Year-crude incidence (\%) & $95 \% \mathrm{Cl}$ & \\
\hline Anaplasma spp. & $38.3(n=112)$ & $27.7-49.7$ & $7.1(n=75)$ & $2.4-15.9$ & $x^{2}=12.76, d f=1, P=0.0004$ \\
\hline Babesia spp. & $96.0(n=49)$ & 79.7-99.9 & $100.0(n=26)$ & $75.3-100.0$ & $x^{2}=0.01, d f=1, P=0.9330$ \\
\hline Dirofilaria immitis & $39.8(n=130)$ & $30.4-50.0$ & $1.3(n=81)$ & $<0.1-6.8$ & $x^{2}=25.05, d f=1, P<0.0001$ \\
\hline Ehrlichia spp. & $58.5(n=84)$ & $44.1-71.9$ & $22.9(n=59)$ & $12.0-37.3$ & $x^{2}=5.57, d f=1, P=0.0183$ \\
\hline Leishmania spp. & $19.6(n=177)$ & $13.5-26.9$ & $43.8(n=115)$ & $32.7-55.3$ & $x^{2}=8.04, d f=1, P=0.0046$ \\
\hline
\end{tabular}

a Except for Dirofilaria immitis and Borrelia burgdorferi (not shown in the table), all pathogens were assessed by both serology and PCR. For more details, see "Methods" Abbreviations: $\mathrm{Cl}$, confidence interval; $n$, number of dogs considered in the calculations; $\mathrm{nc}$, not calculated

As for the other VBPs, higher prevalence values for Anaplasma spp., D. immitis and Ehrlichia spp. were found in Goiana, as compared to São Joaquim de Bicas, which agrees with our previous observations [19]. This is probably due to a higher pressure of ectoparasites in Goiana, which may be related to the infrequent use of ectoparasiticides on dogs, as discussed elsewhere [19]. Indeed, the socioeconomic profile of inhabitants living in the studied municipalities differs in terms of illiteracy rates, human development index, and gross domestic product per capita, according to official data from the Brazilian Institute of Geography and Statistics [27]. In addition, the dog owner attitude towards ectoparasite control also differs, in which the frequency of ectoparasite treatments was found to be higher in São Joaquim de Bicas as compared to Goiana in a previous study [19]. Thus, one could speculate that the higher prevalence of infection by Anaplasma spp. and Ehrlichia spp. in Goiana could be also related to a lower frequency of ectoparasite treatments in dogs from this municipality. However, Babesia spp. infection, contracted via tick infestation, occurred in high prevalence in both regions (further discussed below). The above hypothesis also does not apply to D. immitis, considering that this parasite does not seem to be endemic in São Joaquim de Bicas [19], as in other municipalities of Minas Gerais [16]. On the other hand, D. immitis is highly prevalent in Goiana, as in other municipalities of Pernambuco [16, 19, 28]. The finding of a single faintly positive dog in São Joaquim de Bicas at the follow-up may be a result of a rare, but possible crossreactivity reaction with other parasite antigens [29].

While the serological tests used herein are not always species-specific to A. platys, E. canis and B. vogeli, these are by far the most widespread species belonging to these genera in Brazil [7], including in Pernambuco [30]. For instance, $A$. phagocytophilum has been reported in some occasions in south-eastern Brazil [31], but so far not in the north-eastern region of the country. Ehrlichia ewingii has been suspected in five dogs in south-eastern Brazil [32], but this finding needs further confirmation as reviewed elsewhere [33]. Finally, Babesia gibsoni has been reported on rare occasions in dogs from the southernmost part of Brazil [34], but not elsewhere in this country.

The YCI of some VBPs herein calculated was generally similar to that recorded by molecular and serological tests in sheltered young dogs in southern Italy $[25,35,36]$. In spite of the higher prevalence and YCI of Anaplasma spp. and Ehrlichia spp. in Pernambuco, no significant difference was found in relation to Babesia spp. This is also in line with our previous study, in which we reported high seropositivities for Babesia spp. in both Goiana and São Joaquim de Bicas [19]. This is expected considering that dogs living in the study areas were frequently seen infested by ectoparasites, including Rhipicephalus sanguineus (sensu lato) ticks and Ctenocephalides spp. fleas (data not shown), as reported previously [19].

Because both E. canis and B. vogeli are transmitted by $R$. sanguineus (s.l.), there is no plausible explanation for the similar prevalence of Babesia spp. and the dissimilar prevalence of Ehrlichia spp. in Goiana and São Joaquim de Bicas, but maybe this could be related to distinct patterns of antibody production in dogs against these agents. Considering that the vector competence of different populations of R. sanguineus (s.l.) for E. canis has already been documented [37], our results may suggest that the tick population present in Goiana may be more capable of transmitting $E$. canis as compared to the population of São Joaquim de Bicas. Nonetheless, this could also be related to seasonal patterns to tick infestations on dogs in these municipalities, which could somehow be affecting E. canis, but not $B$. vogeli transmission.

Anti-Borrelia burgdorferi antibodies were not detected in any of the samples from Goiana and São Joaquim de Bicas, which was expected considering the absence of competent vectors in the study areas. While some rare 
positive results have been reported in studies conducted in Brazil and other Latin American countries [38], further studies are needed to confirm the presence and significance (if any) of borreliosis in dogs from this part of the world.

Longitudinal studies on the very same population of dogs are challenging to conduct, especially with privately-owned dogs that are untreated against ectoparasites. One of the major challenges is the high proportion of dogs lost to follow-up, as reported in this study. Therefore, data generated herein will be useful for future studies and analyses, perhaps also for different pathogens not considered herein.

\section{Conclusions}

This study confirms high prevalence and YCI of various VBPs in dogs in two geographical regions of Brazil. Our data also indicate that the risk of infection varies significantly for individual pathogens and between the regions, which may be related to several biotic (e.g. climate and socioeconomic status of dog owners) and abiotic (e.g. vector competence and capacity of different tick populations) factors that are still poorly understood. YCI may be somewhat underestimated in this study considering the ectoparasitic treatments that some dogs received and considering that the LOCF method for missing data at the final follow-up was applied to all dogs concerned, including dogs that were negative at the interim. Such dogs might have become positive until the final followup, but were considered to be negative within the analyses. Still, the impact is expected to be low as only limited numbers of dogs were concerned.

\section{Supplementary information}

Supplementary information accompanies this paper at https://doi. org/10.1186/s13071-020-04056-8.

Additional file 1: Table S1. Total number of dogs tested by serology and PCR for different pathogens at each time point (baseline, after 8 and 12 months), in Goiana (Pernambuco) and São Joaquim de Bicas (Minas Gerais), Brazil. Numbers are expressed as "positive/total (positivity)".

\section{Abbreviations}

Cl: Confidence interval; CNPq: Conselho Nacional de Desenvolvimento Científico e Tecnológico; ELISA: Enzyme-linked immunosorbent assay; IFA: Indirect immunofluorescence; LOCF: Last observation carried forward; NTC: No template control; PCR: Polymerase chain reaction; VBP: Vector-borne pathogens; YCl: Year-crude incidence.

\section{Acknowledgements}

We thank the Secretaria Estadual de Saúde de Pernambuco and Secretaria Municipal de Saúde de Goiana for their logistic support during field activities. Thanks also due to all veterinarians and students involved in the field activities and Gabriela Dantas Torres Guimarães for data quality control. Publication of this paper has been sponsored by Bayer Animal Health in the framework of the 15 th $C V B D^{\circledR}$ World Forum Symposium.

\section{Authors' contributions}

FDT conceived and designed the study. LAF, FDT and VMR collected the samples. KGSS, DEOM, JA, YYS and LGS performed the diagnostic tests. FDT, KGSS and LAF prepared the database. FDT performed the statistical analyses and wrote the first draft. DO, KD, MP and GA provided scientific advice for the study and reviewed the manuscript. All authors read and approved the final manuscript.

\section{Funding}

This study was sponsored by Bayer Animal Health and Idexx Laboratories provided the SNAP 4Dx tests. FDT is the recipient of a research fellowship from the Conselho Nacional de Desenvolvimento Científico e Tecnológico CNPq (CNPq; 313118/2018-3).

\section{Availability of data and materials}

The data supporting the conclusions of this article are included within the article and its additional files. Raw data can be shared with other researchers upon specific request.

\section{Ethics approval and consent to participate}

The Committee on Ethics in the Use of Animals (CEUA, project number: 66/2014) of the Aggeu Magalhães Institute (Fiocruz) approved the procedures used in this study. Dog owners signed a consent form before the inclusion of their animals in this study.

\section{Consent for publication}

Not applicable.

\section{Competing interests}

GA, KD and MP are employees of Bayer Animal Health GmbH. FDT and DO are members of the CVBD World Forum, whose activities are sponsored by Bayer Animal Health. LAF, KGSS, DEOM, JL AA, YYS, LGS, GRV and VMR declare, that they have no competing interests. This study and the publication of this article were sponsored by Bayer Animal Health. IDEXX Laboratories provided the SNAP 4Dx tests.

\section{Author details}

1 Department of Immunology, Aggeu Magalhães Institute, Oswaldo Cruz Foundation (Fiocruz), Recife, Brazil. ${ }^{2}$ Centro Universitário do Vale do Ipojuca (UNIFAVIP/Wyden), Caruaru, Pernambuco, Brazil. ${ }^{3}$ Veterinary School, Pontifical Catholic University of Minas Gerais, Betim, Brazil. ${ }^{4}$ Department of Veterinary Medicine, Università degli Studi di Bari, Valenzano, Bari, Italy. ${ }^{5}$ Faculty of Veterinary Sciences, Bu-Ali Sina University, Hamedan, Iran. ${ }^{6}$ Bayer Animal Health $\mathrm{GmbH}$, Leverkusen, Germany.

Received: 27 January 2020 Accepted: 1 April 2020

Published online: 21 April 2020

\section{References}

1. Otranto D, Dantas-Torres F, Breitschwerdt EB. Managing canine vector-borne diseases of zoonotic concern: part one. Trends Parasitol. 2009;25:157-63.

2. Otranto D, Dantas-Torres F, Breitschwerdt EB. Managing canine vector-borne diseases of zoonotic concern: part two. Trends Parasitol. 2009;25:228-35.

3. de Caprariis D, Dantas-Torres F, Capelli G, Mencke N, Stanneck D, Breitschwerdt EB, et al. Evolution of clinical, haematological and biochemical findings in young dogs naturally infected by vector-borne pathogens. Vet Microbiol. 2011;149:206-12.

4. De Tommasi AS, Otranto D, Dantas-Torres F, Capelli G, Breitschwerdt EB, Caprariis D. Are vector-borne pathogen co-infections complicating the clinical presentation in dogs? Parasites Vectors. 2013;6:97.

5. Dantas-Torres F, Otranto D. Best practices for preventing vector-borne diseases in dogs and humans. Trends Parasitol. 2016;32:43-55.

6. Traub RJ, Irwin P, Dantas-Torres F, Tort GP, Labarthe NV, Inpankaew T, et al. Toward the formation of a Companion Animal Parasite Council for the Tropics (CAPCT). Parasites Vectors. 2015;8:271.

7. Dantas-Torres F, Otranto D. Dogs, cats, parasites, and humans in Brazil: opening the black box. Parasites Vectors. 2014;7:22. 
8. Costa PL, Dantas-Torres F, Silva FJ, Guimarães VC, Gaudêncio K, BrandãoFilho SP. Ecology of Lutzomyia longipalpis in an area of visceral leishmaniasis transmission in north-eastern Brazil. Acta Trop. 2013;126:99-102.

9. Colwell DD, Dantas-Torres F, Otranto D. Vector-borne parasitic zoonoses: emerging scenarios and new perspectives. Vet Parasitol. 2011;182:14-21.

10. Otranto D, Diniz DG, Dantas-Torres F, Casiraghi M, Almeida INF, Almeida LNF, et al. Human intraocular filariasis caused by Dirofilaria sp. nematode, Brazil. Emerg Infect Dis. 2015;17:863-6.

11. Pan American Health Organization. Epidemiological profiles of neglected diseases and other infections related to poverty in Latin America and the Caribbean. https://www.paho.org/hq/dmdocuments/2009/nds-epi-profi les-final-sst-24-set.pdf. Accessed 19 Feb 2020.

12. Martins-Melo FR, Carneiro M, Ramos AN Jr, Heukelbach J, Ribeiro ALP, Werneck GL. The burden of neglected tropical diseases in Brazil, 1990-2016: a subnational analysis from the Global Burden of Disease Study 2016. PLoS Negl Trop Dis. 2018;12:e0006559.

13. Quinnell RJ, Courtenay O, Garcez L, Dye C. The epidemiology of canine leishmaniasis: transmission rates estimated from a cohort study in Amazonian Brazil. Parasitology. 1997;115:143-56.

14. Falqueto A, Ferreira AL, Santos CB, Porrozzi R, Costa MV, Teva A, et al. Cross-sectional and longitudinal epidemiologic surveys of human and canine Leishmania infantum visceral infections in an endemic rural area of southeast Brazil (Pancas, Espírito Santo). Am J Trop Med Hyg. 2009;80:559-65.

15. Ministério da Saúde. Coeficiente de incidência de leishmaniose visceral, por 100.000 habitantes. Brasil, Grandes Regiões e Unidades Federadas. 1990 a 2018. http://portalarquivos2.saude.gov.br/images/pdf/2019/ outubro/14/LV-Coef-Incidencia.pdf. Accessed 30 Dec 2019.

16. Labarthe N, Campos PM, Barbarini O, McKee W, Coimbra CA, Hoskins J. Serologic prevalence of Dirofilaria immitis, Ehrlichia canis, and Borrelia burgdorferi infections in Brazil. Vet Ther. 2003:4:67-75.

17. Carlos RS, Muniz Neta ES, Spagnol FH, Oliveira LL, Brito RL, Albuquerque $G R$, et al. Frequency of antibodies anti-Ehrlichia canis, Borrelia burgdorferi and Dirofilaria immitis antigens in dogs from microrregion Ilhéus-Itabuna, State of Bahia, Brazil. Rev Bras Parasitol Vet. 2007;16:117-20.

18. Costa AP, Costa FB, Labruna MB, Silveira I, Moraes-Filho J, Soares JF, et al. A serological and molecular survey of Babesia vogeli, Ehrlichia canis and Rickettsia spp. among dogs in the state of Maranhão, northeastern Brazil. Rev Bras Parasitol Vet. 2015;24:28-35.

19. Figueredo LA, Sales KGS, Deuster K, Pollmeier M, Otranto D, Dantas-Torres F. Exposure to vector-borne pathogens in privately owned dogs living in different socioeconomic settings in Brazil. Vet Parasitol. 2017;243:18-23.

20. Dantas-Torres F, Silva YY, Miranda DEO, Sales KGS, Figueredo LA, Otranto D. Ehrlichia spp. infection in rural dogs from remote indigenous villages in north-eastern Brazil. Parasites Vectors. 2018;11:139.

21. Francino O, Altet L, Sánchez-Robert E, Rodriguez A, Solano-Gallego L, Alberola J, et al. Advantages of real-time PCR assay for diagnosis and monitoring of canine leishmaniosis. Vet Parasitol. 2006;137:214-21.

22. Dantas-Torres F, Sales KGS, Silva LG, Otranto D, Figueredo LA. LeishmaniaFAST15: a rapid, sensitive and low-cost real-time PCR assay for the detection of Leishmania infantum and Leishmania braziliensis kinetoplast DNA in canine blood samples. Mol Cell Probes. 2017;31:65-9.

23. Kordick SK, Breitschwerdt EB, Hegarty BC, Southwick KL, Colitz CM, Hancock SI, et al. Coinfection with multiple tick-borne pathogens in a walker hound kennel in North Carolina. J Clin Microbiol. 1999;37:2631-8.

24. Beall MJ, Chandrashekar R, Eberts MD, Cyr KE, Diniz PP, Mainville C, et al. Serological and molecular prevalence of Borrelia burgdorferi, Anaplasma phagocytophilum, and Ehrlichia species in dogs from Minnesota. Vector Borne Zoonotic Dis. 2008;8:455-64.

25. Otranto D, de Caprariis D, Lia RP, Tarallo V, Lorusso V, Testini G, et al. Prevention of endemic canine vector-borne diseases using imidacloprid $10 \%$ and permethrin $50 \%$ in young dogs: a longitudinal field study. Vet Parasitol. 2010;172:323-32.

26. Esch KJ, Pontes NN, Arruda P, O'Connor A, Morais L, Jeronimo SM, et al. Preventing zoonotic canine leishmaniasis in northeastern Brazil: pet attachment and adoption of community Leishmania prevention. Am J Trop Med Hyg. 2012;87:822-31.

27. Instituto Brasileiro de Geografia e Estatística (IBGE). Cidades. http://www. cidades.ibge.gov.br/xtras/home.php. Accessed 19 Feb 2020.

28. Labarthe NV, Paiva JP, Reifur L, Mendes-de-Almeida F, Merlo A, Carvalho Pinto CJ, et al. Updated canine infection rates for Dirofilaria immitis in areas of Brazil previously identified as having a high incidence of heartworm-infected dogs. Parasites Vectors. 2014;7:493.

29. Venco L, Manzocchi S, Genchi M, Kramer LH. Heat treatment and falsepositive heartworm antigen testing in ex vivo parasites and dogs naturally infected by Dirofilaria repens and Angiostrongylus vasorum. Parasites Vectors. 2017;10:476.

30. Ramos R, Ramos C, Araújo F, Oliveira R, Souza I, Pimentel D, et al. Molecular survey and genetic characterization of tick-borne pathogens in dogs in metropolitan Recife (north-eastern Brazil). Parasitol Res. 2010;107:1115-20.

31. Santos HA, Thomé $S M$, Baldani $C D$, Silva CB, Peixoto MP, Pires MS, et al. Molecular epidemiology of the emerging zoonosis agent Anaplasma phagocytophilum (Foggie, 1949) in dogs and ixodid ticks in Brazil. Parasites Vectors. 2013;6:348.

32. Oliveira LS, Oliveira KA, Mourão LC, Pescatore AM, Almeida MR, Conceição $L G$, et al. First report of Ehrlichia ewingii detected by molecular investigation in dogs from Brazil. Clin Microbiol Infect. 2009;15:55-6.

33. Vieira RF, Biondo AW, Guimarães AM, Santos AP, Santos RP, Dutra LH, et al. Ehrlichiosis in Brazil. Rev Bras Parasitol Vet. 2011;20:1-12.

34. Trapp SM, Messick JB, Vidotto O, Jojima FS, Morais HS. Babesia gibsoni genotype Asia in dogs from Brazil. Vet Parasitol. 2006;141:177-80.

35. Otranto D, Dantas-Torres F, de Caprariis D, Di Paola G, Tarallo VD, Latrofa MS, et al. Prevention of canine leishmaniosis in a hyper-endemic area using a combination of $10 \%$ imidacloprid/4.5\% flumethrin. PLOS ONE. 2013:8:e56374

36. Dantas-Torres F, Capelli G, Giannelli A, Ramos RA, Lia RP, Cantacessi C, et al. Efficacy of an imidacloprid/flumethrin collar against fleas, ticks and tick-borne pathogens in dogs. Parasites Vectors. 2013;6:245.

37. Moraes-Filho J, Krawczak FS, Costa FB, Soares JF, Labruna MB. Comparative evaluation of the vector competence of four South American populations of the Rhipicephalus sanguineus group for the bacterium Ehrlichia canis, the agent of canine monocytic ehrlichiosis. PLoS ONE. 2015;10:e0139386.

38. Maggi RG, Krämer F. A review on the occurrence of companion vector-borne diseases in pet animals in Latin America. Parasites Vectors. 2019;12:145.

\section{Publisher's Note}

Springer Nature remains neutral with regard to jurisdictional claims in published maps and institutional affiliations.

Ready to submit your research? Choose BMC and benefit from:

- fast, convenient online submission

- thorough peer review by experienced researchers in your field

- rapid publication on acceptance

- support for research data, including large and complex data types

- gold Open Access which fosters wider collaboration and increased citations

- maximum visibility for your research: over $100 \mathrm{M}$ website views per year

At BMC, research is always in progress.

Learn more biomedcentral.com/submissions 